\title{
Book Department
}

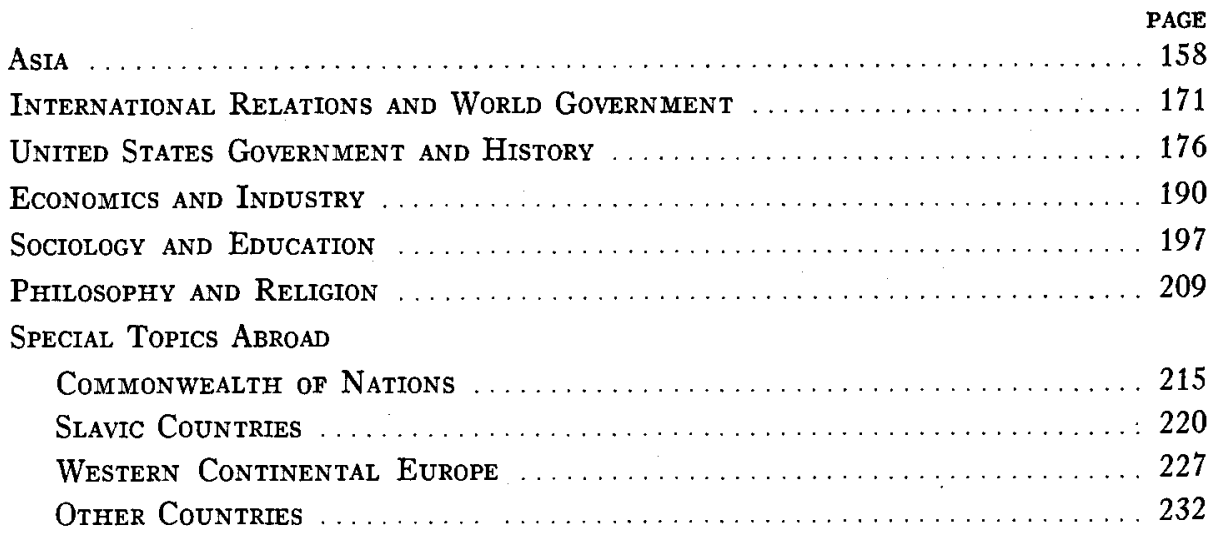

$A S I A$

FaIRBank, John King. Trade and Diplomacy on the China Coast: The Opening of the Treaty Ports, 1842-1854. Vol. I, text, pp. xiii, 489; Vol. II, notes, pp. 88. Cambridge, Mass.: Harvard University Press, 1953. \$7.50 each volume.

This is an excellent account of the establishment of modern treaty relations with China from the first Anglo-Chinese war to the inauguration of the "foreign" inspectorate of the maritime customs. A distinctive feature of the volume is its attention to the Chinese documents and to the interpretation of events "in Chinese terms."

Within the brief period of twelve years the early treaty and treaty port system reached the point of breakdown as had the Canton system before it. The author does not follow the new difficulties to the second war; he ends his account with the inauguration of the inspectorate which he regards as the key institution (p. 462) in the new relations which were being worked out.

The general reader, if he can be induced to look into a work that seems highly specialized, will be rewarded by a beautifully drawn picture of the early negotiator for the Manchu Court, Chi Ying, whose effort was to bring the British barbarian under civilized control by a real sugar plum or two (p. 105) but chiefly by the sugar plums of trade. He will find, also, a neat exposition of the double hypocrisy of the opium trade of the time and may reflect upon the difference in the blinders worn by the Chinese and the British officials. $\mathrm{He}$ will find a lively description of the confusion at Shanghai during the Taiping rebellion.

The historian who undertakes to deal adequately with early Chinese-Western relations must be more than historian; he must be anthropologist, sociologist, political scientist, economist; and he can hardly avoid, if he has any imagination, an excursion into the philosophy of history as well. He must perform services of analysis and generalization beyond any narrow call of duty. The author accepts this with good courage, and his generalizations demand attention especially in the present state of Sino-Western relations.

$\mathrm{He}$ finds his significant generalizations in the fields of politics and diplomacy rather than in that of trade. There is, for example, a tantalizing reference (p. 297) to the extension of tea production in China but no examination of the nature of the industrial or economic organization which was soon to prevent China from meeting 
Indian competition in a growing world market. The general effects-and possibilities—of trade are not explored, which may be accepted as further evidence that the chief importance of the early trade lay in the diplomatic and general international relations of the country.

The Chinese imperial system, which the author rightly considers one of the world's great political achievements, was the empirical fact and the theoretical concept into which, from the Chinese viewpoint, the new relations with the West had to be fitted. This was done, as the author sees it, by taking the Westerner into the system. The adjustment to the Manchu-Chinese dyarchy took the form of the inspectorate of customs and a "synarchy" came into existence. The institutions of the Chinese system were, and may still be, tough and adaptable. Thinking along these lines leads to the conclusion that the theory of imperialism is "not the only avenue of approach" (p. 468) to the problem.

Generalizations of quite a different sort seem at times to be on the point of formulation. There is reference (pp. 22, 468) to a landlord-gentry-scholar-official league against the peasantry in an agrarian-bureaucratic state. This seems to point in the direction of class struggle and to be inconsistent in its implications with the powerful traditions of the Chinese system.

If these powerful political traditions may be called Confucian, the current situation may be put into some such questions as these: Is a neo-Confucian solution of the political, social, and economic problem of China a possibility? How might China's relations with the West and with Russia fit into such a solution? By these questions exactly a century is spanned, from 1854 to 1954.

\section{University of Michigan}

$$
\text { C. F. REMER }
$$

SwISHer, EARL. China's Management of the American Barbarians: A Study of Sino-American Relations, 1841-1861, with Documents. Pp. xxi, 844. New Haven, Conn.: Far Eastern Publications, Yale University (for the Far Eastern Association), 1953. No price.
This handsome volume, the second monograph in the series sponsored by the Far Eastern Association, breaks new ground in the study of Sino-American relations and prepares the way for Western research on a new level of sophistication and control of the sources. One of the pioneers in the American study of nineteenth century China through Chinese sources, Professor Swisher here presents translations of 546 Chinese documents, most of them in extenso and few of them ever before available to the non-Chinese-reading researcher. They make available from the archives of the Manchu emperors the basic and originally secret documentation of the Chinese side of Sino-American relations in the fateful decades from 1841 to 1861 . Though published in a photo-lithographed edition of the originally secret imperial compilation in 1930 and since then referred to by many scholars, the content of these documents has never before been so fully laid forth in English.

Professor Swisher's introduction gives the fullest account yet available of how these documents came into being and how they are related to other $\mathrm{Ch}^{\prime}$ ing archives and publications. Of these 546 documents he finds that 19 have hitherto been available in English and that less than 200 of them are available in Chinese in other collections than the special one on foreign affairs which is here translated (the I-wu shih-mo series). Mr. Swisher began the process of selection and translation at Harvard in 1933, and continued it in Peking in 1937-38 and again in 1947-48. The results as now published, with a full complement of the necessary scholarly apparatus, form a landmark in the Iong and arduous process of understanding Chinese institutions and their functioning in foreign affairs.

Professor Swisher contributes three initial chapters on the handling of Chinese foreign affairs, the Chinese personnel involved in dealing with the United States, and the attitudes of Chinese officialdom toward this country in the middle decades of the nineteenth century. He then supplies introductions to the fourteen chapters in which the 546 documents are arranged, followed by a glossary of Chinese personal names with 